\title{
Temporal and spatial variability of phytoplankton photosynthetic characteristics in a southern European estuary (Douro, Portugal)
}

\author{
Isabel C. Azevedo ${ }^{1,2, *}$, Pedro Duarte ${ }^{2,3}$, Adriano A. Bordalo ${ }^{1,2}$ \\ ${ }^{1}$ Laboratório de Hidrobiologia, Instituto de Ciências Biomédicas Abel Salazar (ICBAS), Universidade do Porto, \\ Lg. Abel Salazar 2, 4099-003 Porto, Portugal \\ ${ }^{2}$ Centro Interdisciplinar de Investigação Marinha e Ambiental (CIIMAR), Rua dos Bragas 289, 4050-123 Porto, Portugal \\ ${ }^{3}$ Global Change, Energy, Environment and Bioengineering R \& D Unit (CIAGEB), Faculdade de Ciências e Tecnologia, \\ Universidade Fernando Pessoa, Praça 9 de Abril 349, 4249-004 Porto, Portugal
}

\begin{abstract}
The timescales of variability in photosynthetic parameters and the relationships between environmental variables and photosynthetic response are important issues for an accurate estimation of phytoplankton primary production, a major feature of aquatic systems. In the present study, variability in phytoplankton photosynthetic parameters of the Douro estuary was analyzed using data from photosynthesis-irradiance $(P-E)$ incubations performed during seasonal tidal cycles, as well as during monthly surveys carried out along a salinity gradient. Tidal surveys were conducted in October 2003 and January, May, and July 2004. Monthly surveys were conducted from December 2002 to December 2003. Diel variability in $P$-E parameters was highest during the summer survey. The highest values of the biomass-specific maximum photosynthetic rate $P_{\max }$ were generally observed around noon or in the afternoon, and correlated positively with photosynthetic efficiency $\alpha$. Seasonal variability in $P_{\max }$ and $\alpha$ was mostly related to temperature and light, whereas photoacclimation seemed to be the most important factor in diel variability. Spatially, variability increased upstream for mean $P_{\max }$ and $\alpha$ values, associated with higher chlorophyll a concentration and temperature. By combining a temperature-limiting function with the Steele $P$-E equation, $60 \%$ of $P_{\max }$ variation was explained. Analysis of inter-seasonal, intra-seasonal, and diel variability of photosynthetic parameters suggests that, in the Douro, photosynthetic parameters $P_{\max }$ and $\alpha$ are most variable at a seasonal timescale, while for optimal light intensity $E_{\text {opt }}$, diel variability was, as expected, highest. Thus, predictive models of primary productivity should take into account this seasonal variability when looking at larger timescales.
\end{abstract}

KEY WORDS: P-E parameters · Phytoplankton $\cdot$ Seasonal and diel variability $\cdot$ Primary production · River discharge $\cdot$ Douro estuary

\section{INTRODUCTION}

The relationship between photosynthesis and light (the $P$-E relationship) has been used for many years as a tool to estimate phytoplankton production over several temporal and spatial scales (Harding et al. 1982, Falkowski \& Raven 1997). This relationship has been described by several mathematical formulations, which may be empirical, based on observations (Steele 1962,
Webb et al. 1974, Jassby \& Platt 1976, Platt et al. 1980), or mechanistic, based on physiological processes (Eilers \& Peeters 1988). These references correspond to static formulations, where $P$-E parameters are assumed to be constant in time. However, temporal variability of photosynthetic parameters is now well established, with several authors suggesting that this dynamic behavior should be included in P-E models (Falkowski \& Wirick 1981, Marra et al. 1985, Sakshaug et al. 1997, Duarte 2005). 
Variability in photosynthetic parameters has been studied over different timescales and found to be related to endogenous circadian rhythms (Prezelin 1992) as well as to changes in environmental variables such as light intensity (Gallegos et al. 1983, Geider et al. 1996, Madariaga 2002), species composition (Cote \& Platt 1983, Jouenne et al. 2005), water temperature (e.g. Tillmann et al. 2000), and salinity (Moisander et al. 2002).

Several of these factors may be simultaneously implied in photosynthetic variability of natural phytoplankton assemblages, especially in systems subjected to highly variable environmental conditions, such as estuaries. MacCaull \& Platt (1977) have already hypothesized that photosynthetic variability observed in the field is related to both endogenous rhythms and changing environmental factors. Actually, environmental variability can act directly at the level of physiology within phytoplankton species (Lizon et al. 1995, Duarte et al. 2006), as well as indirectly through changes on species composition, which in turn cause variations in photosynthesis-irradiance relationships (Cote \& Platt 1983, Macedo et al. 2001, Jouenne et al. 2005).

Previous studies (Cote \& Platt 1983, 1984) have shown that, by emphasizing the influence of environmental and biological factors on the photosynthetic parameters rather than on the instantaneous rate of photosynthesis, a better understanding of the factors controlling the activity of phytoplankton in their natural environment can be achieved. Moreover, knowledge of the relationships between environmental variables and photosynthetic response allows the development of reliable mathematical models that can be used to calculate photosynthetic rates based on light, temperature, nutrient concentrations, and chlorophyll a (chl a) concentration as input variables (Sakshaug et al. 1997).

The Douro estuary is characterized by a highly variable freshwater inflow, controlled by a network of $>50$ large dams. In a previous paper (Azevedo et al. 2008), we presented a conceptual model of the Douro estuary, showing that the river emerges as the major source of nutrients, chl $a$, and total particulate matter (TPM), although additional phosphate and TPM anthropogenic sources are present in the middle and lower, highly urbanized, estuarine stretches. Water column salinity structure and freshwater residence time are dependent on river flow magnitude. Flows $>800 \mathrm{~m}^{3} \mathrm{~s}^{-1}$ prevent seawater from entering the estuary (Vieira \& Bordalo 2000), whereas for flows $<300 \mathrm{~m}^{3} \mathrm{~s}^{-1}$, salinity stratification occurs. During spring, when flow decreases and light availability and temperature increase, phytoplankton biomass and primary production (PP) reach their maximum within the estuary. During the summer low river flow period, when temperature and water transparency are the highest (as well as salinity), chl $a$ and PP decline.

The Douro is a mostly heterotrophic estuary, with heterotrophy increasing towards the mouth, where this condition is observed all year round. Only in the upper reaches and only during spring was an autotrophic state observed (Azevedo et al. 2006).

In Azevedo et al. (2006), annual PP was estimated from $P-E$ measurements along the Douro estuary. Strong correlations were found between the maximum photosynthetic rate $P_{\max }$, temperature, and chl a concentration, suggesting that these environmental variables were responsible for most of the variability observed in that photosynthetic parameter. Those findings paved the way for the present study, whose objective is to answer the following questions: (1) At which temporal scales is the variability of $P-E$ parameters more important? (2) How important is the spatial variability of the $P$-E parameters, along the estuarine gradient, given the complex mixing patterns between fresh- and saltwater phytoplankton? (3) What are the most important environmental factors affecting the variability of $P-E$ parameters?

\section{MATERIALS AND METHODS}

Study area. The Douro estuary is a granitic drowned valley estuary, heavily modified in its last $8 \mathrm{~km}$, corresponding to the limit between upper and middle estuarine stretches (Fig. 1). It is characterized by semidiurnal tides, with a mean tidal range of $2.8 \mathrm{~m}$, and a pronounced seasonal river flow regime $\left(0\right.$ to $13000 \mathrm{~m}^{3}$ $\mathrm{s}^{-1}$; average $505 \mathrm{~m}^{3} \mathrm{~s}^{-1}$ ). During floods and under low river discharge, the salt wedge reaches the head of the estuary, and remains within the estuary during the next ebb. During high-discharge events, the estuary is flushed completely during one tidal cycle and seawater intrusion is prevented during the flood (Vieira \& Bordalo 2000).

Sampling. The present work is based on 2 sampling approaches: (1) tidal cycle surveys at a single anchor station near the mouth and (2) monthly surveys at 3 stations located in the lower, middle, and upper reaches. The latter was used previously in a study on the pelagic metabolism of the Douro estuary (Azevedo et al. 2006) and will be further analyzed in the present work regarding the variability of $P$-E parameters at different timescales.

River flow data were obtained from the Portuguese water authority (INAG).

Tidal cycles: Sampling was carried out on 28 October 2003 and 23 January, 18 May, and 29 July 2004. Quasi-continuous surface and bottom measurements (every minute) of water temperature, salinity, dis- 
solved oxygen (DO), and pH were taken with CTD probes (YSI, 6600); current velocity and direction were measured with Valeport (model 106) current meters. Incident irradiance (photosynthetically active radiation [PAR]) was measured with a spherical quantum sensor light meter (LI-COR, LI-250). Surface and bottom samples were collected every $2 \mathrm{~h}$ for nutrient and chl $a$ quantification. Subsurface samples for $P$-E incubations were collected in the morning (around 09:00 h), around noon, and in the afternoon (around 15:00 h). Secchi disk depth was measured for water column light attenuation assessment.

Monthly surveys: From December 2002 to December 2003, monthly surveys, during ebb and flood tide, were conducted during a 13 mo cycle for PP and pelagic metabolism assessment of the Douro estuary (Azevedo et al. 2006). Briefly, sampling design consisted of visits to 3 stations located in the lower, middle, and upper estuary, at approximately $0.7,5.0$, and $21.6 \mathrm{~km}$ from the river mouth, respectively (Fig. 1). Sampling was performed twice a month, during ebb and flood tide. Vertical profiles of temperature, conductivity, salinity, dissolved oxygen, $\mathrm{pH}$, and turbidity were performed with a CTD (YSI, 6600). PAR profiles were obtained with a spherical quantum sensor light meter, at $0.5 \mathrm{~m}$ depth steps (LI-COR, LI-250). Simultaneously, subsurface samples were collected for chl $a$, nutrients (nitrate, nitrite, ammonium, phosphate, and silicate), and PP assessments.

Analytical and experimental procedures. Dissolved orthophosphate, nitrite, ammonium, and silicate were analyzed following the methods described in Grasshoff et al. (1983). Nitrate was quantified by an adaptation of the spongy cadmium reduction technique (Jones 1984), subtracting nitrite from the total. Analyses were

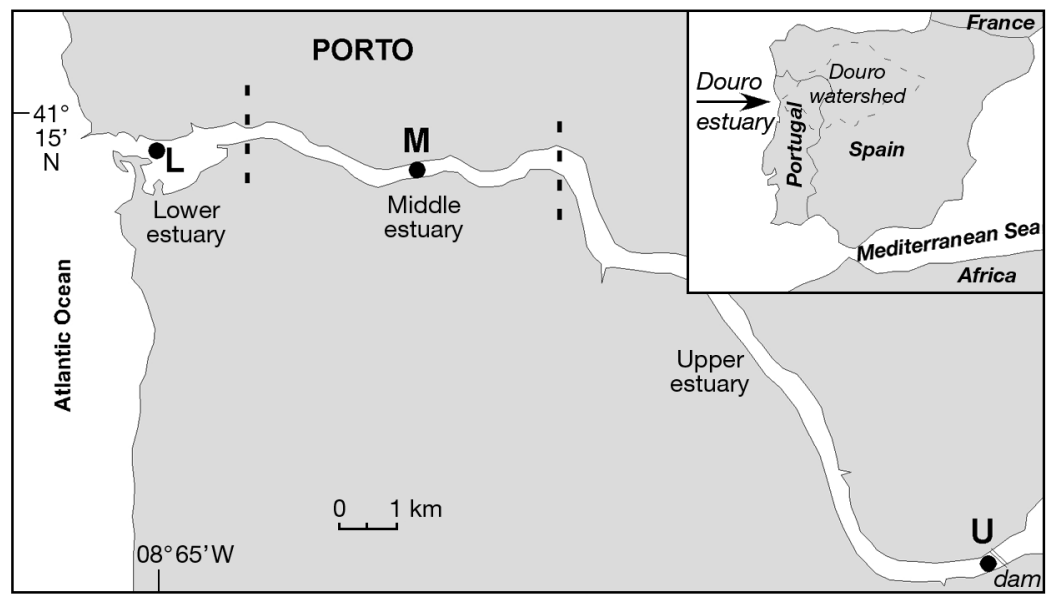

Fig. 1. Location of sampling stations. Stns L (lower), M (middle), and U (upper) represent stations visited during annual surveys. Seasonal tidal cycles were performed at an anchor station in the vicinity of Stn L. Dashed lines represent limits of the lower, middle and upper estuarine stretches performed in triplicate. Chl a was assayed spectrophotometrically after extraction with $90 \%$ acetone (Parsons et al. 1984) with cell homogenization, using the SCOR-UNESCO (1966) trichromatic equation. P-E experiments were performed by the ${ }^{14} \mathrm{C}$ method (Steeman Nielsen 1952). Samples were placed in $125 \mathrm{ml}$ Pyrex glass flasks and $2 \mu \mathrm{Ci}$ of aqueous solution of sodium bicarbonate was added (Carbon 14 Centralen). Incubations were conducted at 5 light levels $(100,75$, 50,25 , and $1 \%$ ), to mimic light attenuation at different depths within the euphotic zone, for 1 to $2 \mathrm{~h}$ in a water bath, at in situ temperature. An artificial light source providing a PAR of $920 \mu \mathrm{mol}$ photons $\mathrm{m}^{-2} \mathrm{~s}^{-1}$ was used. A neutral screen was used to provide the different light levels. One additional dark bottle was also incubated. After incubation, samples were filtered through $0.45 \mu \mathrm{m}$ membranes, washed, and placed in $20 \mathrm{ml}$ scintillation vials, and a $10 \mathrm{ml}$ scintillation cocktail (Beckman Instagel Packard) was added. Counts, in disintegrations per minute (DPM), were performed in a Beckman LS3801 liquid scintillation analyzer using internal standards for the automatic establishment of the quenching curve. Dark DPM values were subtracted from light DPM values and results were expressed in $\mathrm{mg} \mathrm{C} \mathrm{m}^{-3} \mathrm{~h}^{-1}$. Inorganic carbon was assayed from $\mathrm{pH}$ and alkalinity measurements by direct titration according to Parsons et al. (1984).

Data analysis. P-E parameter estimation: Steele's (1962) production-light function (Eq. 1) was used to fit $P$ - $E$ curves to experimental data from incubation experiments, using the Gauss-Newton non-linear regression method, since photoinibition was apparent. Photosynthetic rates were normalized to chl $a$. Chlorophyll-specific maximum photosynthetic rate $P_{\max }$ and optimal light intensity $E_{\text {opt }}$ were obtained directly from the fitted $P-E$ curves. Photosynthetic efficiency $\alpha$ was estimated as the initial slope of the $P$-E curves by deriving Steele's function in relation to light intensity $E$ and calculating the limit of the derivative when $E$ approaches zero.

$$
P=P_{\max }\left[\frac{E}{E_{\text {opt }}} \exp \left(1-\frac{E}{E_{\text {opt }}}\right)\right]^{\mathrm{n}}
$$

where $\mathrm{n}=1$ ( $\mathrm{n}$ is an empirical integer).

Statistical and multivariate analyses: Spearman rank correlation analysis was performed to evaluate the relationships between environmental and biological variables and metabolic processes. To analyze spatial variability in photosynthetic parameters, a 1-way multivariate analysis of variance (MANOVA) was carried out. In this case, all values (26) measured at each station over the 13 mo 
sampling period were used as surrogates for replicates. The Wilks test was computed and the NewmanKeuls test was applied a posteriori.

Principal component analysis (PCA) was performed using Statistica Software in order to investigate patterns of similarity between samples (Q-mode analysis) based on the contribution of environmental variables and photosynthetic parameters. The data matrix was organized with samples as rows and observations (variables) as columns. Data were standardized to account for the different units in which the variables were expressed.

Photosynthetic parameter variability at different timescales: In order to establish the temporal scale at which variability of photosynthetic parameters was highest, inter-seasonal (MS1) and intra-seasonal (MS2) variance were calculated, according to Eqs. (2) \& (3), respectively, using the monthly surveys data set.

$$
\begin{gathered}
\text { MS1 }=\frac{\sum_{i=1}^{\mathrm{n}}\left(\bar{x}_{i}-\bar{x}_{a}\right)^{2}}{n-1} \\
\text { MS2 }=\frac{\sum_{i=1}^{\mathrm{n}}\left(\sum_{j=1}^{\mathrm{n}}\left(\bar{x}_{i j}-\bar{x}_{i}\right)^{2}\right)}{(k-1) \cdot n}
\end{gathered}
$$

where $\bar{x}_{a}$ is the annual mean; $\bar{x}_{i}$ is the seasonal mean; $\bar{x}_{i j}$ is the monthly mean, based on results from 3 sampling stations $\times 2$ occasions; $n$ is the number of seasons; and $k$ is the number of months from each season.

The tidal cycle data set was used to compare seasonal and diel variability, according to the same equations, except that in this case $\bar{x}_{i j}$ is a single value corresponding to time of day and $k$ is the number of samples taken on each day.

Each pair of variances was compared by computing their ratio and performing an F-test. Since photosynthetic parameters were not sampled randomly over time and space, this comparison between their variances at different timescales may be biased. Additionally, coefficients of variation (CV) were calculated for the same timescales.

Temperature and phosphate integration in Steele's P-E equation: A previous study on the pelagic metabolism of the Douro estuary (Azevedo et al. 2006) showed that PP was mostly controlled by temperature. Also, in this system, the N:P ratio is generally above the Redfield ratio, suggesting an excess of nitrogen availability and a potential limiting role for phosphate (Azevedo et al. 2008). Thus, in order to investigate the effect of including these factors in PP estimation, Steele's equation was combined with an exponential limiting function for temperature and a Michaelis-Menten limiting function for phosphate. The resulting model (Eq. 4) was adjusted to data obtained from incubations per- formed during the monthly surveys, using the GaussNewton non-linear regression method.

$P=P_{\max }\left[\frac{E}{E_{\text {opt }}} \exp \left(1-\frac{E}{E_{\text {opt }}}\right)\right]^{n} \exp \left(\mathrm{k}_{T} T\right)\left(\frac{P h}{P h+K p}\right)$

where $\mathrm{k}_{T}$ is the temperature augmentation rate in $\left({ }^{\circ} \mathrm{C}\right)^{-1}, \mathrm{~T}$ is temperature in ${ }^{\circ} \mathrm{C}, \mathrm{Ph}$ is phosphate concentration in $\mu \mathrm{M}$, and $K p$ is the half-saturation constant for phosphate in $\mu \mathrm{M}$.

\section{RESULTS}

\section{Environmental variables}

Results presented in this section are based on the tidal cycle surveys. Environmental variability in the monthly surveys was presented in Azevedo et al. (2006).

River flow into the estuary was controlled by the dam discharge activity at the head. Hourly variability was high, with abrupt changes observed during all sampling periods, according to the needs of hydroelectricity (Fig. 2). In the fall survey, flow rose from 800 to 1400
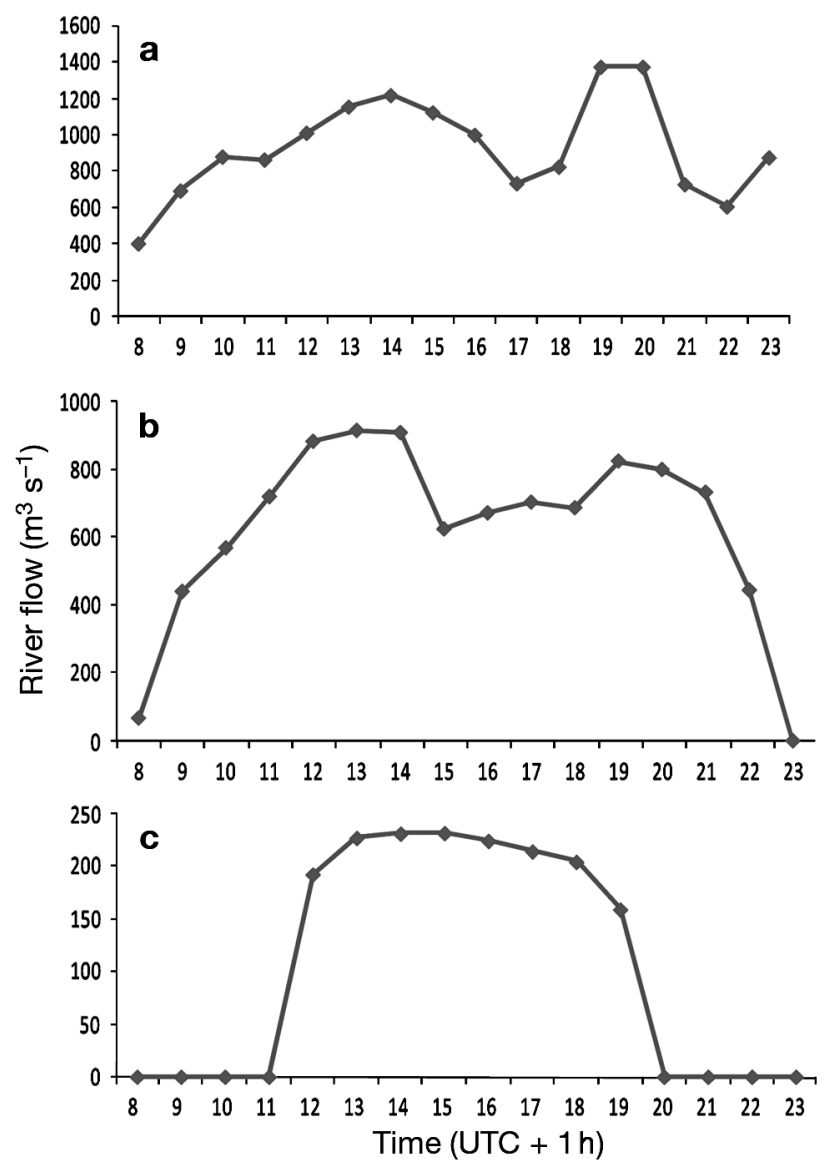

Fig. 2. Hourly river flow during the (a) fall, (b) winter, and (c) summer tidal cycle surveys. Data for the spring survey were not available 
$\mathrm{m}^{3} \mathrm{~s}^{-1}$ and dropped back to $700 \mathrm{~m}^{3} \mathrm{~s}^{-1}$ in $3 \mathrm{~h}$. In the winter survey, a $300 \mathrm{~m}^{3} \mathrm{~s}^{-1}$ drop was observed, between 14:00 and 15:00 h, from 900 to $600 \mathrm{~m}^{3} \mathrm{~s}^{-1}$, whereas in the summer survey, river flow was $0 \mathrm{~m}^{3} \mathrm{~s}^{-1}$ between 08:00 and 11:00 h, rose to around $200 \mathrm{~m}^{3} \mathrm{~s}^{-1}$ until 18:00 $\mathrm{h}$ and then dropped back to $0 \mathrm{~m}^{3} \mathrm{~s}^{-1}$ at 20:00 h.

Salinity values observed during the sampling surveys were dependent on tidal conditions and river flow (Fig. 3). At the bottom, salinity increased during the flood, except in the summer survey, when values remained high throughout the entire survey due to the absent/reduced freshwater discharge from the dam. During winter and spring, a drop in salinity was observed after the turn of the tide, due to high river flow which pushed seawater downstream and caused
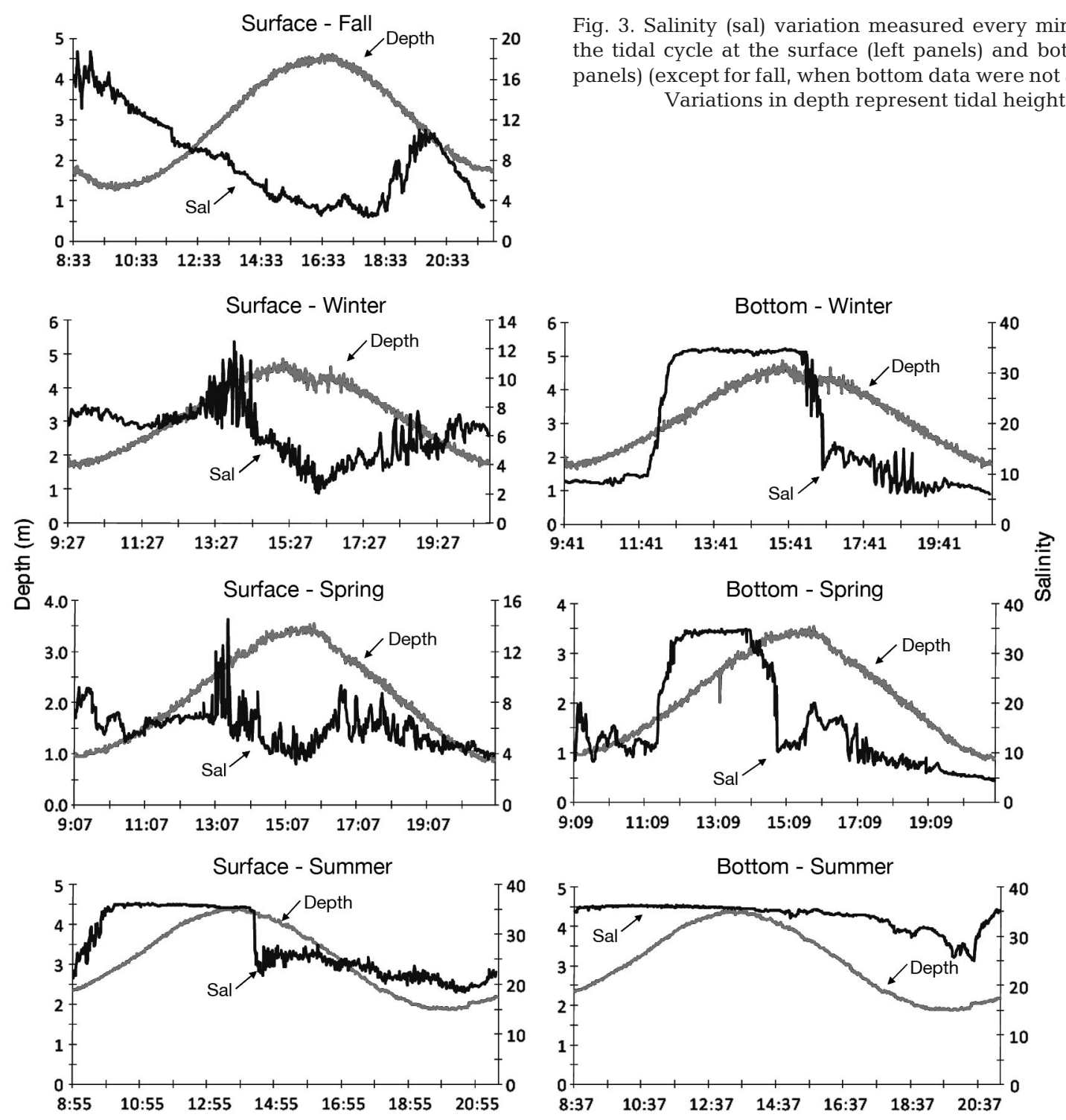

Fig. 3. Salinity (sal) variation measured every minute along the tidal cycle at the surface (left panels) and bottom (right panels) (except for fall, when bottom data were not available).

Variations in depth represent tidal heights

de-stratification of the water column. The influence of river flow on salinity was also evident at the surface. Values decreased during the flood in all surveys, coincident with river flow increase. This was very noticeable in the summer survey: surface salinity remained high throughout the period of absence of freshwater discharge, decreasing about $2.5 \mathrm{~h}$ after the dam started discharging. This salinity decrease was accompanied by an increase in temperature and oxygen saturation. Moreover, salinity stratification of the water column was recurrent throughout the surveys during high tide.

Nitrate, phosphate, and silicate concentrations were higher during the fall, winter, and spring surveys and lower during summer, when the influence of low-nutrient coastal water was more noticeable. Ammonium was higher during the spring and summer surveys and

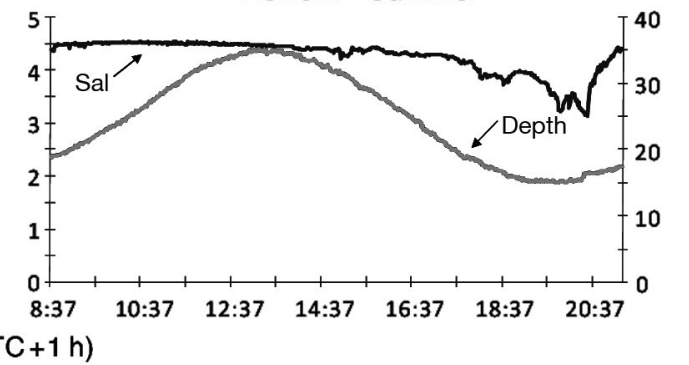


Table 1. Descriptive statistics of environmental variables measured during seasonal tidal cycles. CV: coefficient of variation (\%); $\mathrm{O}_{\text {sat }}$ : oxygen saturation

\begin{tabular}{|c|c|c|c|c|c|c|c|c|c|}
\hline Season & Salinity & $\begin{array}{c}\text { Temperature } \\
\left({ }^{\circ} \mathrm{C}\right)\end{array}$ & $\begin{array}{c}\text { Nitrate } \\
(\mu \mathrm{M})\end{array}$ & $\begin{array}{c}\text { Ammonium } \\
(\mu \mathrm{M})\end{array}$ & $\begin{array}{c}\text { Phosphate } \\
(\mu \mathrm{M})\end{array}$ & $\begin{array}{c}\text { Silicate } \\
(\mu \mathrm{M})\end{array}$ & $\begin{array}{l}\mathrm{O}_{\text {sat }} \\
(\%)\end{array}$ & $\mathrm{pH}$ & $\begin{array}{c}\text { Chl a } \\
\left(\mathrm{mg} \mathrm{m}^{-3}\right)\end{array}$ \\
\hline \multicolumn{10}{|l|}{ Fall } \\
\hline Mean & 13.2 & 16.6 & 51.1 & 10.0 & 1.4 & 31.0 & 95.6 & 8.1 & 2.7 \\
\hline $\mathrm{SD}$ & 9.5 & 0.4 & 21.9 & 4.8 & 0.5 & 9.3 & 5.4 & 0.3 & 0.5 \\
\hline Max. & 31.3 & 17.6 & 86.0 & 16.6 & 2.0 & 46.6 & 104.2 & 8.8 & 3.7 \\
\hline Min. & 3.4 & 16.1 & 11.9 & 1.0 & 0.5 & 13.3 & 83.5 & 7.5 & 1.6 \\
\hline CV & 72.2 & 2.3 & 42.9 & 48.2 & 34.0 & 30.0 & 5.6 & 3.6 & 20.0 \\
\hline \multicolumn{10}{|l|}{ Winter } \\
\hline Mean & 12.2 & 10.7 & 69.6 & 11.7 & 1.4 & 48.2 & 92.5 & 9.3 & 1.2 \\
\hline $\mathrm{SD}$ & 8.1 & 1.0 & 24.3 & 4.8 & 0.6 & 15.5 & 18.1 & 0.3 & 0.2 \\
\hline Max. & 32.4 & 13.2 & 103.4 & 21.4 & 2.9 & 66.7 & 141.4 & 10.0 & 1.7 \\
\hline Min. & 6.1 & 10.0 & 23.6 & 1.2 & 0.6 & 12.4 & 56.2 & 8.9 & 0.9 \\
\hline $\mathrm{CV}$ & 66.2 & 9.1 & 35.0 & 41.4 & 38.9 & 32.3 & 19.6 & 3.5 & 17.4 \\
\hline \multicolumn{10}{|l|}{ Spring } \\
\hline Mean & 14.0 & 16.9 & 73.8 & 14.5 & 1.2 & 27.8 & 114.4 & 7.9 & 5.7 \\
\hline $\mathrm{SD}$ & 10.1 & 0.9 & 35.6 & 7.5 & 0.5 & 13.2 & 8.8 & 0.2 & 1.2 \\
\hline Max. & 35.3 & 17.9 & 117.9 & 29.3 & 2.0 & 43.5 & 132.3 & 8.2 & 8.2 \\
\hline Min. & 6.5 & 14.8 & 6.2 & 3.1 & 0.4 & 2.8 & 103.9 & 7.3 & 3.7 \\
\hline $\mathrm{CV}$ & 72.3 & 5.6 & 48.3 & 51.4 & 42.3 & 47.5 & 7.7 & 3.0 & 21.0 \\
\hline \multicolumn{10}{|l|}{ Summer } \\
\hline Mean & 30.2 & 19.2 & 13.4 & 14.2 & 0.9 & 3.7 & 162.7 & 8.5 & 2.8 \\
\hline $\mathrm{SD}$ & 6.1 & 1.5 & 11.9 & 11.1 & 0.6 & 2.4 & 9.6 & 0.5 & 2.3 \\
\hline Max. & 36.8 & 21.2 & 35.3 & 45.0 & 2.4 & 11.3 & 180.3 & 9.0 & 6.2 \\
\hline Min. & 20.0 & 17.1 & 1.0 & 3.0 & 0.3 & 1.1 & 140.9 & 7.9 & 0.3 \\
\hline CV & 20.2 & 7.9 & 88.5 & 78.0 & 62.4 & 64.6 & 5.9 & 5.4 & 83.6 \\
\hline
\end{tabular}

lower in fall and winter. Ranges and averages obtained for each survey are presented in Table 1. Whenever a 2-layer circulation was present, due to salinity stratification, nitrate and phosphate presented a vertical gradient, with higher levels at the surface, corresponding to lower-salinity water (Fig. 4). When a salinity decrease occurred at the surface, due to river flow increase, nutrient levels increased. This was also observed at the bottom, especially during the ebb, due to water column mixing. No clear pattern was observed for ammonium, although higher values were also found at the surface.

For chl a concentration, mean values, SD, CV, and ranges obtained for each survey are given in Table 1. Unlike nutrients, chl a showed no relationship with salinity and, generally, no vertical gradient was observed for this variable during periods of water column stratification. Also, no consistent diel rhythm was observed for the different seasonal surveys.

\section{Photosynthetic parameters}

\section{Temporal analysis}

Using the data set obtained during the seasonal tidal cycles, $P$-E curves were generated (Fig. 5). $P_{\max }$ ranged between 0.7 and $35.2 \mathrm{mg} \mathrm{C} \mathrm{mg} \mathrm{chl} a^{-1} \mathrm{~h}^{-1}$ and $\alpha$ ranged between 0.0043 and $0.1578 \mathrm{mg} \mathrm{C} \mathrm{mg} \mathrm{chl} a^{-1} \mathrm{~h}^{-1}$ ( $\mathrm{mmol}$ photons $\left.\mathrm{m}^{-2} \mathrm{~s}^{-1}\right)^{-1}$. $E_{\mathrm{opt}}$ ranged between 441.9 and $1181.0 \mu \mathrm{mol}$ photons $\mathrm{m}^{-2} \mathrm{~s}^{-1}$, although analysis of fitting results (Fig. 5) shows that this maximal value was overestimated by the model, while $E_{\mathrm{k}}$ (light saturation index, defined as $P_{\max } / \alpha$ ) varied between 162.6 and 434.4 $\mathrm{\mu mol}$ photons $\mathrm{m}^{-2} \mathrm{~s}^{-1}$. Mean values, SD, CV, and ranges of photosynthetic parameters for each seasonal tidal cycle are given in Table 2 . Diel variability of $P_{\max }$ $\alpha, E_{\text {opt }}$ and $E_{\mathrm{k}}$ was highest during the summer survey, whereas the lowest variability was observed during the spring survey for $P_{\max }$ and $\alpha$, and, during winter, for $E_{\mathrm{opt}}$ and $E_{\mathrm{k}}$, as shown by the CV. The lowest and highest values for $P_{\max }$ and $\alpha$ were found in winter and summer, respectively. $P_{\max }$ increased from morning to afternoon, except during the spring survey when the maximum was recorded around noon, whereas $\alpha$ increased from morning to noon in all surveys, remaining relatively constant between noon and afternoon, except in summer when a sharp decrease was observed at this time of day (Fig. 6). No consistent pattern was observed for $E_{\mathrm{k}}$ diel variation. $P_{\max }$ and photosynthetic efficiency correlated positively with $E_{\text {opt, }} E_{\text {o }}$ (light intensity at the surface), $E_{\mathrm{k}}$, temperature, and salinity, and negatively with light extinction coefficient $(\mathrm{k})$ and silicate $(\mathrm{p}<$ 0.01). No correlation with chl a was found for $P_{\max }$ or $\alpha$. 

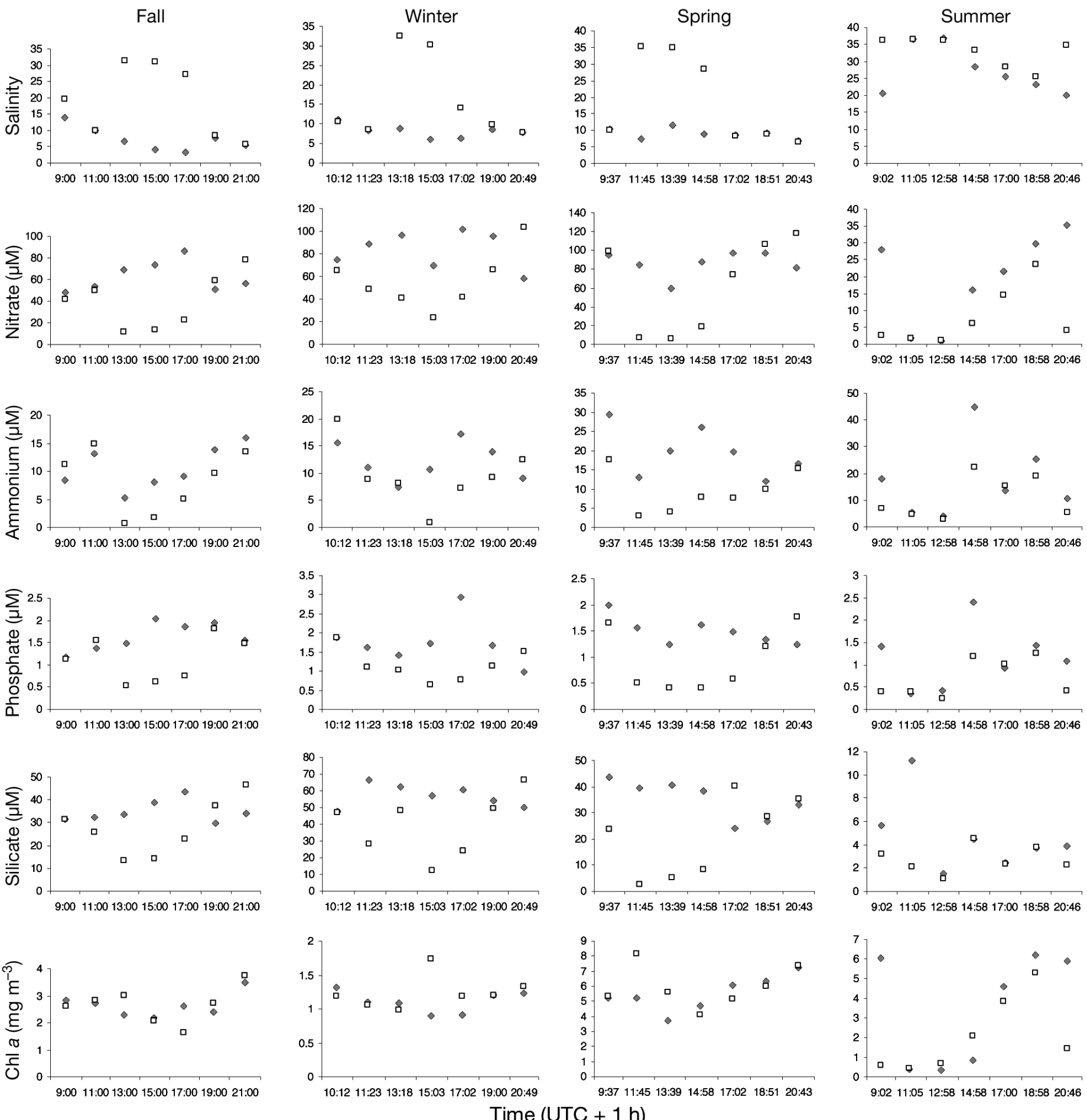

Fig. 4. Salinity, nutrients (nitrate, ammonium, phosphate, and silicate), and chl a variability along the tidal cycle surveys (from left to right columns: fall, winter, spring, summer), sampled along the bottom () and at the surface $(\diamond)$

PCA was performed in order to investigate patterns of similarities between samples based on the contribution of environmental variables and photosynthetic parameters (Fig. 7). The first 2 components (PC1 and PC2) accounted for $66.4 \%$ of the total variation. Vari- ables contributing the most to PC1 were silicate, nitrate, and $\mathrm{k}$ (water column light extinction coefficient; negative semi-axis), and salinity, $P_{\max }$ slope, and $E_{\mathrm{o}}$ (positive semi-axis). Variables contributing the most to $\mathrm{PC} 2$ were $\mathrm{pH}$ and slope (negative semi-axis), and chl $a_{\text {, }}$ 
Table 2. Descriptive statistics of photosynthetic parameters obtained during seasonal tidal cycles. CV: coefficient of variation (\%); $P_{\text {max }}$ : maximum photosynthetic rate; $\alpha$ : photosynthetic efficiency; $E_{\mathrm{opt}}$ : optimal light intensity; $E_{\mathrm{o}}$ : surface light intensity; $E_{\mathrm{k}}$ : light saturation index; $\mathrm{k}$ : light extinction coefficient

\begin{tabular}{|c|c|c|c|c|c|c|c|}
\hline Season & $\begin{array}{c}P_{\max } \\
(\mathrm{mg} \mathrm{C} \mathrm{mg} \\
\left.\text { chl } a^{-1} \mathrm{~h}^{-1}\right)\end{array}$ & 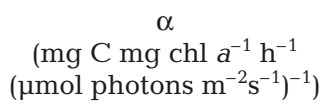 & $\begin{array}{c}E_{\mathrm{opt}} \\
(\mu \mathrm{mol} \text { photons } \\
\left.\mathrm{m}^{-2} \mathrm{~s}^{-1}\right)\end{array}$ & $\begin{array}{c}E_{\mathrm{o}} \\
(\mu \mathrm{mol} \text { photons } \\
\left.\mathrm{m}^{-2} \mathrm{~s}^{-1}\right)\end{array}$ & $\begin{array}{c}E_{\mathrm{k}} \\
(\mu \mathrm{mol} \text { photons } \\
\left.\mathrm{m}^{-2} \mathrm{~s}^{-1}\right)\end{array}$ & $\begin{array}{c}\mathrm{k} \\
\left(\mathrm{m}^{-1}\right)\end{array}$ & $\begin{array}{c}\text { Chl a } \\
\left(\mathrm{mg} \mathrm{m}^{-3}\right)\end{array}$ \\
\hline \multicolumn{8}{|l|}{ Fall } \\
\hline Mean & 2.0 & 0.0094 & 565.8 & 899.5 & 208.2 & 1.1 & 2.4 \\
\hline SD & 0.8 & 0.0029 & 82.8 & 770.4 & 30.5 & 0.1 & 0.4 \\
\hline Max. & 2.6 & 0.0111 & 644.6 & 1484.0 & 237.1 & 1.2 & 2.8 \\
\hline Min. & 1.1 & 0.0061 & 479.4 & 26.5 & 176.4 & 1.1 & 2.2 \\
\hline CV & 41.1 & 30.7 & 14.6 & 85.6 & 14.6 & 6.6 & 14.6 \\
\hline \multicolumn{8}{|l|}{ Winter } \\
\hline Mean & 1.2 & 0.0068 & 475.9 & 16.8 & 175.1 & 1.0 & 1.1 \\
\hline SD & 0.4 & 0.0022 & 42.0 & 6.0 & 15.5 & 0.1 & 0.2 \\
\hline Max. & 1.5 & 0.0082 & 522.9 & 23.7 & 192.4 & 1.1 & 1.3 \\
\hline Min. & 0.7 & 0.0043 & 441.9 & 13.1 & 162.6 & 0.9 & 0.9 \\
\hline $\mathrm{CV}$ & 34.7 & 31.9 & 8.8 & 35.6 & 8.8 & 8.5 & 19.6 \\
\hline \multicolumn{8}{|l|}{ Spring } \\
\hline Mean & 3.2 & 0.0123 & 704.8 & 1433.7 & 259.3 & 0.8 & 5.0 \\
\hline $\mathrm{SD}$ & 0.6 & 0.0006 & 109.3 & 503.8 & 40.2 & 0.1 & 0.3 \\
\hline Max. & 3.8 & 0.0130 & 800.2 & 1729.3 & 294.4 & 0.9 & 5.2 \\
\hline Min. & 2.6 & 0.0119 & 585.5 & 851.9 & 215.4 & 0.7 & 4.7 \\
\hline CV & 19.7 & 4.8 & 15.5 & 35.1 & 15.5 & 10.7 & 6.3 \\
\hline \multicolumn{8}{|l|}{ Summer } \\
\hline Mean & 24.3 & 0.0901 & 751.2 & 1586.8 & 276.3 & 0.6 & 2.4 \\
\hline SD & 15.9 & 0.0637 & 372.4 & 262.9 & 137.0 & 0.2 & 3.2 \\
\hline Max. & 35.2 & 0.1578 & 1181.0 & 1774.8 & 434.4 & 0.8 & 6.0 \\
\hline Min. & 6.0 & 0.0313 & 525.2 & 1286.4 & 193.2 & 0.4 & 0.3 \\
\hline $\mathrm{CV}$ & 65.5 & 70.8 & 49.6 & 16.6 & 49.6 & 40.6 & 131.0 \\
\hline
\end{tabular}

temperature, phosphate, ammonium, $E_{\text {opt }}$, and $E_{\mathrm{o}}$ (positive semi-axis) (Fig. 7a, Tables $3 \& 4$ ). Separation of the summer samples on the positive side of PC1 is explained by higher values of photosynthetic parameters, salinity, temperature, $E_{0}$, and ammonium (cf. Tables 1 $\& 2$ ). The summer noon (Summer_12) sample separation from the other summer samples, along PC2, is explained by its higher slope and salinity as well as lower temperature and ammonium values. Spring observations are characterized by the highest chlorophyll values. Fall samples exhibit higher extinction coefficients and winter values higher silicate concentrations and $\mathrm{pH}$ (Tables 1 \& 2). PP was plotted as a supplementary variable, to avoid autocorrelations with $P_{\max }$ and other photosynthetic parameters (Fig. 7a). The PP position on the PCA factor loadings plot indicates that its variability is mainly related to temperature and light.

\section{Variability at different timescales}

Comparison of inter- and intra-seasonal variance of photosynthetic parameters (with data from the monthly surveys) showed that $P_{\max }$ was significantly $(p<0.05)$ more variable between seasons than within a particular season. Inter-seasonal CVs were, as ex- pected, higher than those for intra-seasonal, especially for $P_{\max }$ and $E_{\text {opt }}(33$ vs. $13 \%$ and 18 vs. $7 \%$, respectively). Using data from tidal cycles, inter-seasonal and diel variances were compared: diel variance was higher for $E_{\text {opt }}$ only; it was lower for $P_{\max }$ and $\alpha$, although no statistical significance was obtained. These observations were confirmed by the CVs calculated for the same timescales.

\section{Spatial analysis}

Spatial analysis of photosynthetic parameters was performed with the monthly surveys data set. $P_{\max }$ ranged between 0.9 and $9.2 \mathrm{mg} \mathrm{C} \mathrm{mg} \mathrm{chl} \mathrm{a}^{-1} \mathrm{~h}^{-1}$, $\alpha$ between 0.0042 and $0.0401 \mathrm{mg} \mathrm{C} \mathrm{mg} \mathrm{chl} a^{-1} \mathrm{~h}^{-1}$ ( $\mu$ mol photons $\left.\mathrm{m}^{-2} \mathrm{~s}^{-1}\right)^{-1}$, and $E_{\mathrm{k}}$ between 137.5 and $692.7 \mu \mathrm{mol}$ photons $\mathrm{m}^{-2} \mathrm{~s}^{-1}$. Average $P_{\max }$ and $\alpha$ increased upstream (Table 5), although no statistically significant differences were found between stations $(\mathrm{p}=$ 0.058), as well as chl a concentration and temperature, variables that presented significant $(p<0.01)$ positive correlations with the photosynthetic parameters. Positive correlations between $P_{\max }$ and chl $a$ and temperature obtained for the entire annual data set were maintained when analyzing each individual station. 

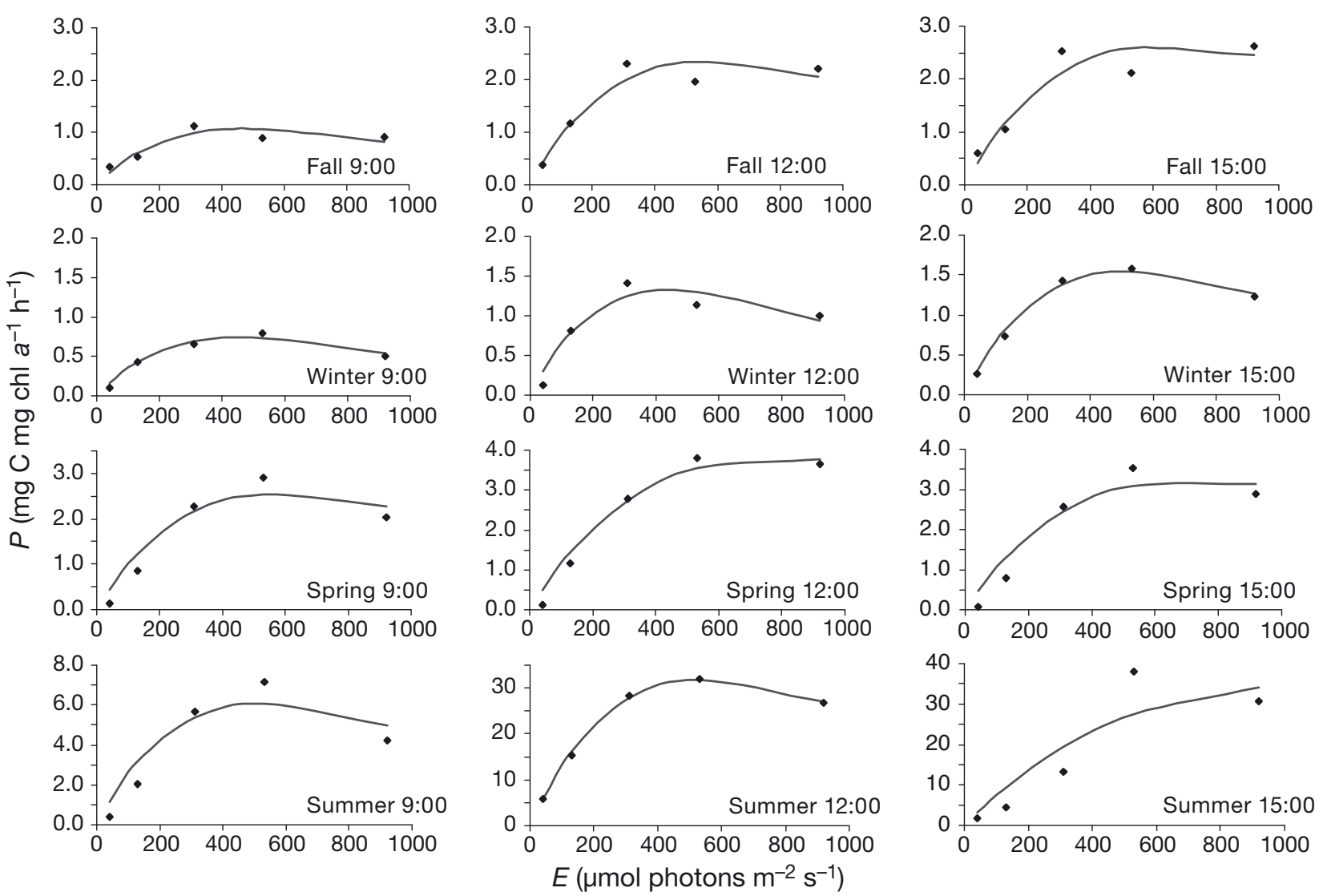

Fig. 5. Photosynthesis-irradiance $(P-E)$ curves obtained from tidal cycle surveys (from upper to lower rows: fall, winter, spring, summer)
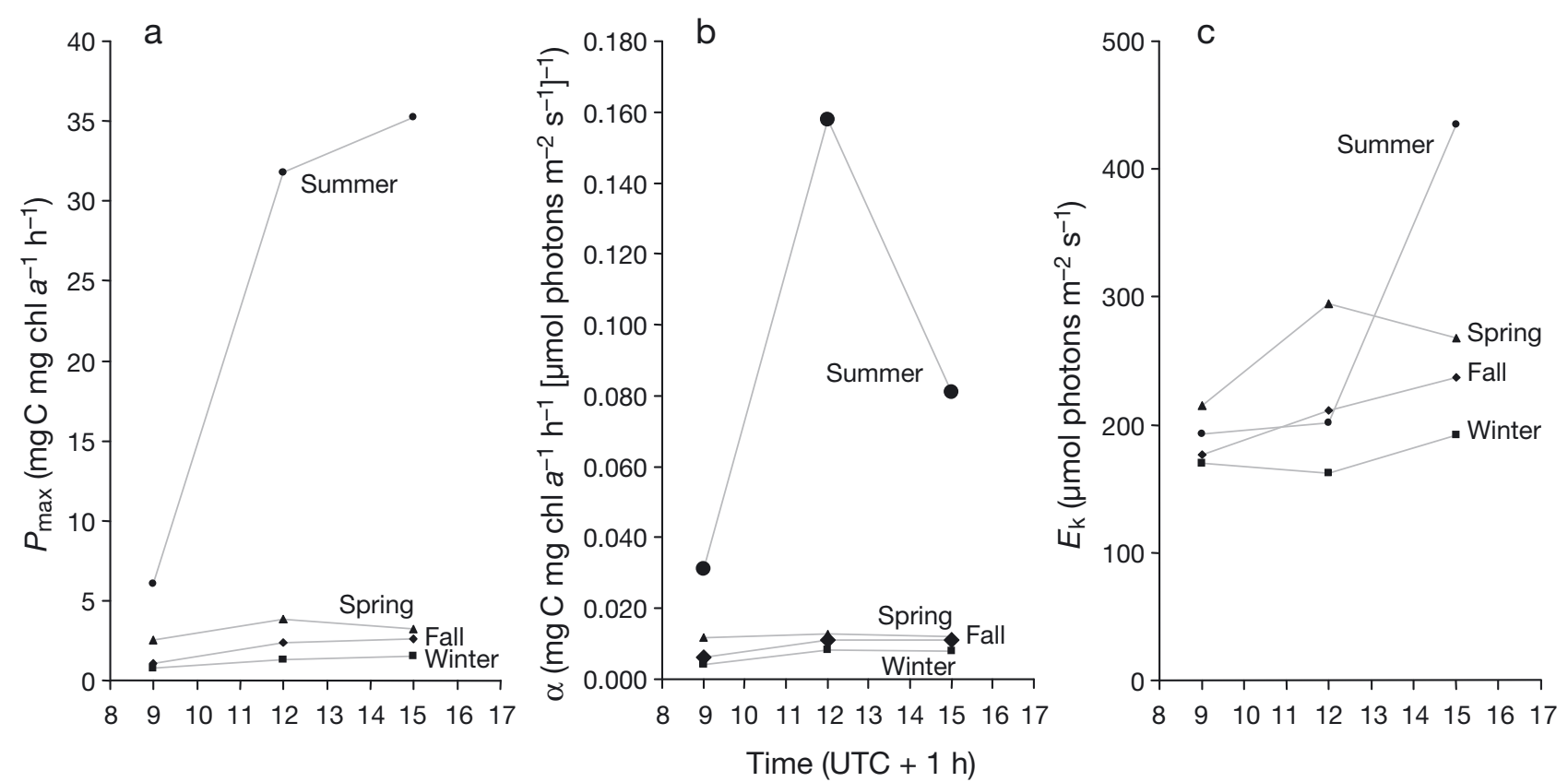

Fig. 6. Diel variation in the photosynthetic parameters (a) maximum photosynthetic rate, $P_{\max }$ (b) photosynthetic efficiency, $\alpha$, and (c) light saturation index, $E_{\mathrm{k}}$ 

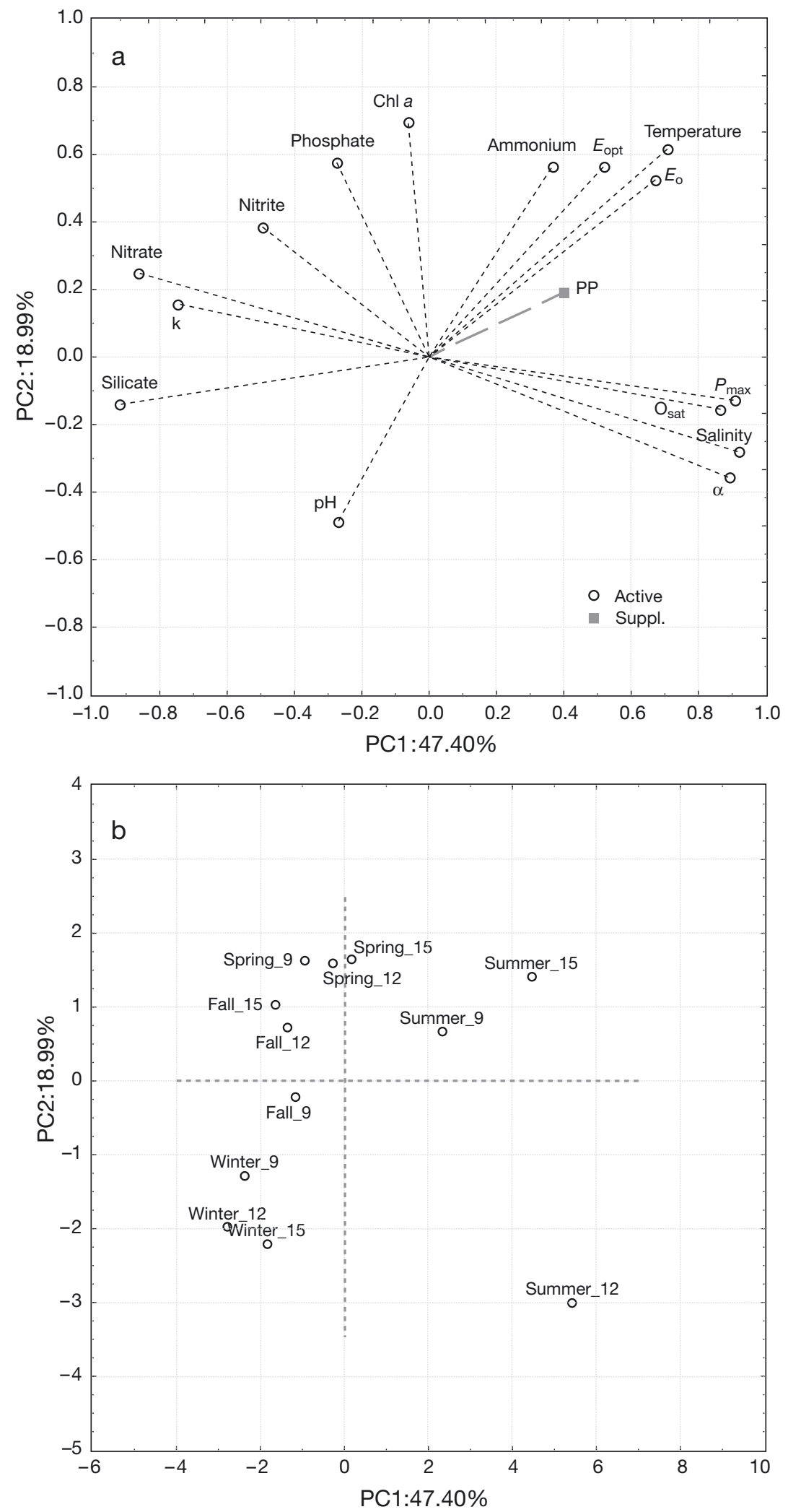

Fig. 7. (a) Principal component analysis (PCA) factor loadings plot. Short-dashed lines show active variables. Long-dashed line shows the supplementary (suppl.) variable (primary production [PP] in $\mathrm{mg} \mathrm{C} \mathrm{mg} \mathrm{chl} \mathrm{a}^{-1} \mathrm{~h}^{-1}$ ). $E_{\mathrm{opt}}$ : optimal light intensity; $E_{\mathrm{o}}$ : light surface intensity; k: light extinction coefficient; $\mathrm{O}_{\text {sat }}$ : oxygen saturation; $P_{\max }$ : maximum photosynthetic rate. (b) Projection of samples in the space defined by the first 2 principal components. See Tables $3 \& 4$ for eigenvectors and eigenvalues obtained from this analysis, respectively 
Table 3. Eigenvectors or coefficients in the linear combinations of variables making up principal components PC1 and PC2 (see Fig. 7a). $P_{\max }$ : maximum photosynthetic rate; $E_{\text {opt: }}$ optimal light intensity; $E_{\mathrm{o}}$ : surface light intensity; k: light extinction coefficient; $\mathrm{O}_{\text {sat }}$ : oxygen saturation

\begin{tabular}{|lrr|}
\hline Variable & PC1 & \multicolumn{1}{c|}{ PC2 } \\
\hline$P_{\max }$ & 0.339933 & -0.076083 \\
$E_{\mathrm{opt}}$ & 0.194003 & 0.333635 \\
$E_{\mathrm{o}}$ & 0.252131 & 0.311150 \\
$\mathrm{k}$ & -0.279851 & 0.092081 \\
Slope & 0.334038 & -0.210436 \\
Chl a & -0.023711 & 0.413150 \\
Nitrate & -0.323362 & 0.147159 \\
Nitrite & -0.185818 & 0.228479 \\
Ammonium & 0.137369 & 0.333957 \\
Phosphate & -0.102858 & 0.341734 \\
Silicate & -0.345212 & -0.082295 \\
Temperature & 0.265266 & 0.366236 \\
Salinity & 0.345129 & -0.165726 \\
O & 0.324632 & -0.091561 \\
pH & -0.100998 & -0.289331 \\
\hline
\end{tabular}

Table 4. Eigenvalues, percent variation, and cumulative variation for each of the first 5 principal components (PC)

\begin{tabular}{|lccc|}
\hline PC & Eigenvalue & \% Variation & \% Cum. variation \\
\hline 1 & 7.1 & 47.4 & 47.4 \\
2 & 2.8 & 19.0 & 66.4 \\
3 & 2.4 & 15.7 & 82.1 \\
4 & 1.4 & 9.2 & 91.3 \\
5 & 0.6 & 3.9 & 95.1 \\
\hline
\end{tabular}

\section{Temperature and phosphate integration in Steele's $P$-E equation}

The empirical model integrating light, temperature, and phosphate (Eq. 4) was tested with data from incubations performed during the monthly surveys. Although $55 \%$ of variance in photosynthetic parameters was accounted for using this model, higher than the $44 \%$ found when considering only irradiation, $K p$ was $<0$, and thus without biological meaning. Using a function combining the Steele equation and temperature only, $60 \%$ of variation was explained, with parameter estimates of $1.5 \mathrm{mg} \mathrm{C} \mathrm{mg} \mathrm{chl} a^{-1} \mathrm{~h}^{-1}$ for $P_{\max }, 576.6 \mu \mathrm{mol}$ photons $\mathrm{m}^{-2} \mathrm{~s}^{-1}$ for $E_{\mathrm{opt}}$, and $0.0378{ }^{\circ} \mathrm{C}^{-1}$ for $\mathrm{k}_{T}$ (Table 6). The model was also applied to data from individual seasons, in order to investigate different (seasonal) response patterns to those environmental variables. Biologically significant parameters were obtained for spring and fall, with total variance of 67 and $82 \%$ explained, respectively (Table 6, Fig. 8).

\section{DISCUSSION}

\section{Environmental variability}

The high variability of environmental characteristics observed during seasonal tidal cycles was mainly due to river flow control by the dam located at the upper estuary. River flow magnitude influenced water column stratification, which was observed around high tide during all

Table 5. Descriptive statistics of photosynthetic parameters obtained during annual surveys at the 3 stations along the estuary. $\mathrm{CV}$ : coefficient of variation (\%); $P_{\text {max }}$ : maximum photosynthetic rate; $\alpha$ : photosynthetic efficiency; $E_{\text {opt }}$ optimal light intensity; $E_{\mathrm{o}}$ : surface light intensity; $E_{\mathrm{k}}$ : light saturation index; $\mathrm{k}$ : light extinction coefficient

\begin{tabular}{|c|c|c|c|c|c|c|c|}
\hline Stn & $\begin{array}{c}P_{\max } \\
(\mathrm{mg} \mathrm{C} \\
\left.\operatorname{mg~} \operatorname{chl~} a^{-1} \mathrm{~h}^{-1}\right)\end{array}$ & $\begin{array}{c}\alpha \\
\left(\mathrm{mg} \mathrm{C} \mathrm{mg} \mathrm{chl} a^{-1} \mathrm{~h}^{-1}\right. \\
\left.\left(\mu \mathrm{mol} \text { photons } \mathrm{m}^{-2} \mathrm{~s}^{-1}\right)^{-1}\right)\end{array}$ & $\begin{array}{c}E_{\mathrm{opt}} \\
(\mu \mathrm{mol} \text { photons } \\
\left.\mathrm{m}^{-2} \mathrm{~s}^{-1}\right)\end{array}$ & $\begin{array}{c}E_{\mathrm{o}} \\
(\mu \mathrm{mol} \text { photons } \\
\left.\mathrm{m}^{-2} \mathrm{~s}^{-1}\right)\end{array}$ & $\begin{array}{c}E_{\mathrm{k}} \\
(\mu \mathrm{mol} \text { photons } \\
\left.\mathrm{m}^{-2} \mathrm{~s}^{-1}\right)\end{array}$ & $\begin{array}{c}\mathrm{k} \\
\left(\mathrm{m}^{-1}\right)\end{array}$ & $\begin{array}{c}\text { Chl a } \\
\left(\mathrm{mg} \mathrm{m}^{-3}\right)\end{array}$ \\
\hline \multicolumn{8}{|l|}{ Stn L } \\
\hline Mean & 2.3 & 0.0118 & 529.5 & 980.8 & 194.8 & 1.2 & 3.0 \\
\hline SD & 1.0 & 0.0044 & 88.8 & 686.3 & 32.7 & 0.7 & 1.7 \\
\hline Max. & 5.1 & 0.0195 & 722.9 & 2782.0 & 266.0 & 2.9 & 6.2 \\
\hline Min. & 0.9 & 0.0046 & 373.8 & 70.0 & 137.5 & 0.3 & 0.7 \\
\hline $\mathrm{CV}$ & 43.9 & 36.9 & 16.8 & 70.0 & 16.8 & 58.1 & 56.4 \\
\hline \multicolumn{8}{|l|}{ Stn $\mathbf{M}$} \\
\hline Mean & 2.9 & 0.0130 & 637.8 & 1051.3 & 234.6 & 1.5 & 3.7 \\
\hline $\mathrm{SD}$ & 1.2 & 0.0046 & 278.3 & 722.6 & 102.4 & 0.8 & 2.7 \\
\hline Max. & 5.6 & 0.0233 & 1882.8 & 2741.0 & 692.7 & 4.1 & 10.5 \\
\hline Min. & 1.3 & 0.0042 & 408.9 & 70.0 & 150.4 & 0.5 & 0.5 \\
\hline $\mathrm{CV}$ & 40.2 & 35.2 & 43.6 & 68.7 & 43.6 & 54.4 & 74.3 \\
\hline \multicolumn{8}{|l|}{ Stn U } \\
\hline Mean & 3.1 & 0.0147 & 578.8 & 1051.3 & 212.9 & 1.0 & 4.6 \\
\hline $\mathrm{SD}$ & 1.6 & 0.0066 & 112.0 & 722.6 & 41.2 & 0.0 & 3.8 \\
\hline Max. & 9.2 & 0.0401 & 812.5 & 2741.0 & 298.9 & 1.0 & 14.9 \\
\hline Min. & 1.0 & 0.0045 & 379.9 & 70.0 & 139.8 & 0.8 & 0.8 \\
\hline CV & 50.4 & 45.0 & 19.3 & 68.7 & 19.3 & 4.1 & 82.3 \\
\hline
\end{tabular}


Table 6. Parameters obtained by integration of temperature and phosphate-limiting functions using the Steele equation (Eq. 1). T: temperature; $P h$ : phosphate; $P_{\max }$ : maximum photosynthetic rate; $E_{\text {opt }}$ optimal light intensity; $k_{T}$ : temperature augmentation rate; $K p$ : phosphate half-saturation constant

\begin{tabular}{|c|c|c|c|c|c|c|c|c|c|}
\hline \multirow[b]{2}{*}{ Dataset } & \multicolumn{4}{|c|}{$\longrightarrow P-E$ with $T-$} & \multirow[b]{2}{*}{$P_{\max }$} & \multirow{2}{*}{$\overline{E_{\mathrm{opt}}}$} & \multicolumn{2}{|c|}{$P$-E with $T$ and $P h$} & \multirow[b]{2}{*}{$\begin{array}{l}\text { Variance } \\
\text { explainec }\end{array}$} \\
\hline & $P_{\max }$ & $E_{\text {opt }}$ & $\mathrm{k}_{T}$ & $\begin{array}{l}\text { Variance } \\
\text { explained }\end{array}$ & & & $\mathbf{k}_{T}$ & $K p$ & \\
\hline All data & 1.47 & 576.7 & 0.0378 & 0.60 & 1.41 & 578.1 & 0.0334 & a & 0.56 \\
\hline Winter & 1.25 & 454.4 & 0.0292 & 0.37 & 1.27 & 452.3 & 0.0182 & $\mathrm{a}$ & 0.38 \\
\hline Spring & 1.24 & 566.0 & 0.0546 & 0.73 & 1.48 & 564.4 & 0.0601 & 0.3443 & 0.69 \\
\hline Summer & 2.04 & 643.4 & 0.0325 & 0.76 & 1.29 & 643.3 & 0.0502 & a & 0.77 \\
\hline Fall & 3.56 & 606.8 & a & 0.74 & 3.77 & 608.9 & 0.0150 & 1.1373 & 0.82 \\
\hline
\end{tabular}

sampling periods, coincident with the increase of river flow during that tidal interval. This river flow effect was particularly noticed during the summer survey, being responsible for the sharp salinity decrease at the surface observed $2.5 \mathrm{~h}$ after the dam started discharging. River flow magnitude and water column stratification also influenced nutrient temporal and vertical distribution. In most estuaries, nutrient concentration is often related to river flow magnitude (Jordan et al. 1991, Balls 1992,

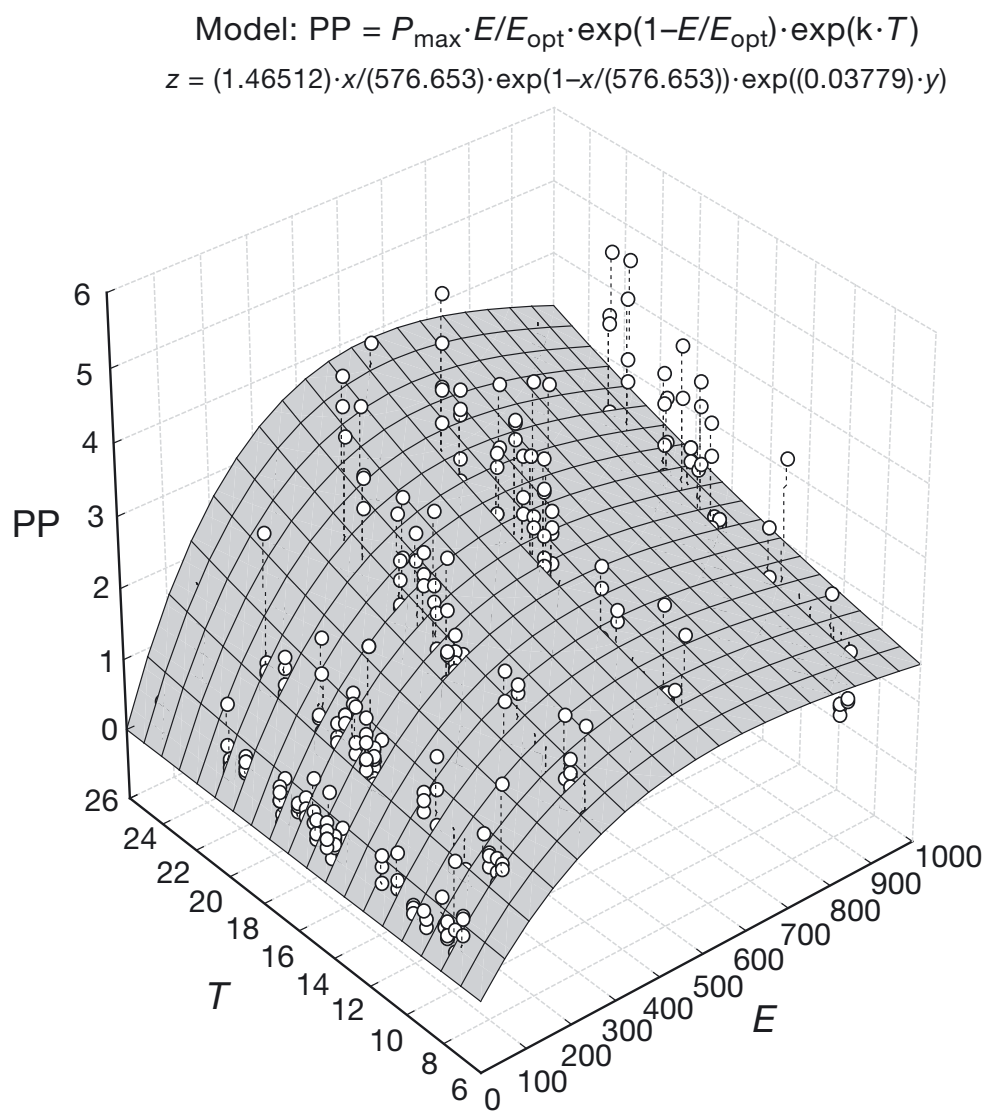

Fig. 8. Model results obtained by integration of temperature and phosphate-limiting functions using the Steele equation (Eq. 1). PP: primary production ( $\left.\mathrm{mgC} \mathrm{mg} \mathrm{chl} a^{-1} \mathrm{~h}^{-1}\right) ; T$ : temperature $\left({ }^{\circ} \mathrm{C}\right) ; E$ : light intensity $\left(\mu \mathrm{mol}\right.$ photons $\mathrm{m}^{-2} \mathrm{~s}^{-1}$ )
Snow et al. 2000, Pastuszak et al. 2003). Pereira-Filho et al. (2001) reported a tide-nutrient relationship, with a nutrient decrease during the flood and high tide and an increase during the ebb. In the present study, such a relationship was not found, due to water column stratification: levels at the surface remained high throughout the flood due to the presence of a lower-salinity surface layer, resulting from river flow. A similar pattern would be expected for chl a distribution, since previous work in the Douro presented evidence that phytoplankton originates mostly from the river (Bordalo \& Vieira 2005, Azevedo et al. 2008). The general absence of a vertical gradient in chl a concentration during periods of water column stratification could be explained by the sinking of phytoplankton cells, due to their specific weight generally exceeding that of the water. Sinking rates depend on morphology, motility, physiological state, density, and viscosity of the medium, as well as water circulation (Pitcher et al. 1989). Sinking rates of 0.5 to $0.9 \mathrm{~m} \mathrm{~d}^{-1}$ for estuaries have been reported, although for oceans the range is much broader, reaching $25 \mathrm{~m} \mathrm{~d}^{-1}$ (Huisman \& Sommeijer 2002 and references therein). Assuming a sinking rate of a few meters per day, during periods of lower river flow, and higher residence times, a vertical uniform distribution of phytoplankton may be achieved. In the Douro estuary, residence time is $>1 \mathrm{~d}$ for river flows $<300 \mathrm{~m}^{3} \mathrm{~s}^{-1}$, which is characteristic of spring and summer periods when phytoplankton biomass is higher.

\section{Photosynthetic variability}

The ranges obtained for photosynthetic parameters $P_{\max }$ and $\alpha$ were broader than in other systems reported in the literature (Cote \& Platt 1983, Goosen et al. 1999, Basterretxea \& Aristegui 2000, Tillmann et al. 2000, 
Macedo et al. 2001, Jouenne et al. 2005, Struski \& Bacher 2006) although similar to the range reported by Boyer et al. (1993) for the temperate Neuse River estuary (0.14 to $33.9 \mathrm{mg} \mathrm{C} \mathrm{mg} \mathrm{chl} \mathrm{a}^{-1} \mathrm{~h}^{-1}$ for $\left.P_{\max }\right)$. The highest values were obtained during the summer tidal cycle survey, in the noon and afternoon samples, when $P_{\max }$ exceeded the theoretical maximum of $25 \mathrm{mg} \mathrm{C} \mathrm{mg}$ chl $a^{-1} \mathrm{~h}^{-1}$, according to Falkowski (1981). This may be explained by the low chl a concentration of these samples (0.40 and $0.86 \mathrm{mg} \mathrm{m}^{-3}$, respectively), due to the influence of chl a-poor coastal waters. This problem has also been reported by Lohrenz et al. (1994) in coastal waters of the Gulf of Mexico, except that in the present study, rates of carbon fixation obtained for these samples were not low (around $10 \mathrm{mg} \mathrm{C} \mathrm{m}^{-3} \mathrm{~h}^{-1}$ ), suggesting the presence of a low biomass but highly productive phytoplankton. The presence of low biomass and high PP was previously detected in the lower Douro estuary (Bordalo 1991). In addition, Lohrenz et al. (1994) calculated the maximum theoretical limit for $\alpha$ of $0.11 \mathrm{mg} \mathrm{C} \mathrm{mg} \mathrm{chl} a^{-1} \mathrm{~h}^{-1}$ ( $\mu \mathrm{mol}$ photons $\left.\mathrm{m}^{-2} \mathrm{~s}^{-1}\right)^{-1}$. Values above these limits were only obtained for one of the samples mentioned above, the noon summer survey sample.

$E_{\mathrm{k}}$ has frequently been used to describe the physiological adjustments of algal populations to changing environmental conditions (Cote \& Platt 1983, Macedo et al. 2001), expressing phytoplankton photoacclimational state (Sakshaug et al. 1997, Behrenfeld et al. 2004). In the present study, $E_{\mathrm{k}}$ levels were within the range reported for other coastal systems (Lohrenz et al. 1994, Tillmann et al. 2000, Macedo et al. 2001, Struski \& Bacher 2006).

\section{Temporal variability}

Positive correlation of $P_{\max }$ with temperature is a feature common to most studies (Cote \& Platt 1983, Lohrenz et al. 1994, MacIntyre \& Cullen 1996, Tillmann et al. 2000), and is consistent with $P_{\max }$ being a function of the enzymatic reactions carried out in photosynthesis (Cote \& Platt 1983). $P_{\max }$ also presented a positive correlation with salinity and incident light but negative with $\mathrm{k}$ and silicate, reflecting the seasonal variability observed for this parameter.

The localization of samples in the PCA sample ordination plot (Fig. 7b) allows the linking of environmental characteristics and photosynthetic parameters with different sampling occasions, explaining the clusters formed by samples from different seasons. From PCA it is clear that seasonal variability is higher than diel variability, since samples from the same seasonal tidal cycles were grouped together, with the exception of summer samples, which were spread along PC2, re- flecting changes in nutrients, chl a concentrations, and photosynthetic parameters (with emphasis on the initial slope $\alpha$ ) during that survey (Fig. 4). Summer and winter surveys were projected at opposite extremes relative to $\mathrm{PC} 1$, contrasting higher $P-E$ values, irradiance, temperature, and salinity (summer) to higher $\mathrm{k}$ and nutrient levels (winter). Higher values of the supplementary variable PP were observed during the summer surveys, associated with higher values of photosynthetic parameters, temperature, and salinity.

Variability in $P-E$ parameters has been divided by Behrenfeld et al. (2004) into $E_{\mathrm{k}}$-dependent variability, associated with independent changes in $P_{\max }$ and $\alpha$ that alter $E_{\mathrm{ki}}$ and $E_{\mathrm{k}}$-independent variability, associated with parallel changes in $P_{\max }$ and $\alpha$, with little influence on $E_{\mathrm{k}}$. The former results predominantly from physiological adjustments to changing light conditions (photoacclimation), whereas for the latter no clear physiological explanation has been found. The positive correlation between $P_{\max }$ and $\alpha$ observed in the present study was also reported by other authors (Cote \& Platt 1983, Lohrenz et al. 1994, Jouenne et al. 2005, Struski \& Bacher 2006), suggesting a predominance of $E_{\mathrm{k}^{-}}$ independent variability. This phenomenon could be due to the high environmental variability observed throughout the surveys. The high physicochemical and biological variability that characterizes estuarine systems may complicate short-term photoacclimation (Jouenne et al. 2005).

Diel variability has been attributed to a combination of endogenous physiological oscillations as well as responses to environmental factors (Prezelin 1992, Binder \& DuRand 2002). In highly variable systems, such as estuaries, in which photic and mixing conditions may vary on an hourly basis, consistent patterns of diel variability of photosynthetic parameters are more difficult to observe. Maximal $P_{\max }$ values observed around noon or in the afternoon in the Douro estuary were consistent with previously reported observations in other coastal systems (Lohrenz et al. 1994, Basterretxea \& Aristegui 2000, Jouenne et al. 2005). Previous studies in other temperate estuaries observed a tidal signal in $P_{\max }$ variability: lower $P_{\max }$ at low tide and higher at high tide (Goosen et al. 1999, Jouenne et al. 2005), which may be related to different phytoplankton populations moving up and down the estuary with the tide. In the present study, tidal cycles were always initiated in the morning during low tide, which means that high tide coincided with noon. This allowed the reduction of variability due to different tidal situations but, on the other hand, prevented the analysis of tidal influence on $P$-E parameters.

Analysis of inter-seasonal, intra-seasonal, and diel timescale variability of photosynthetic parameters suggests that in the Douro, photosynthetic parameters 
$P_{\max }$ and $\alpha$ are most variable at a seasonal timescale, while for $E_{\mathrm{opt}}$ diel variability was highest. Thus, predictive models of PP should take into account this seasonal variability, when estimating PP over larger timescales.

\section{Spatial variability}

In the Douro estuary, $P_{\max }$ values were higher at the upstream station, although without statistical significance ( $p=0.058)$, and different spatial patterns of variability were observed in each period. This is the opposite of observations in other systems. In the Neuse River estuary, Boyer et al. (1993) found an inverse spatial pattern, a declining $P_{\max }$ with distance from the estuary mouth, attributed to acclimation to lower light levels of the riverine phytoplankton communities. In the maximum turbidity zone of the Westerschelde, Goosen et al. (1999) observed a lower specific rate of photosynthesis in the more upstream stations, attributed to riverine phytoplankton meeting saline conditions. The pattern observed in the Douro may be explained by higher temperatures in the upstream station, which is confirmed by a positive correlation between those 2 variables. A positive correlation was also obtained with chl $a$, unusual in coastal ecosystems, attributed to the relatively low phytoplankton biomass, preventing intraspecific competition from lowering photosynthetic capacity, on the one hand, and the physiology of phytoplankton related to their origin in a semi-lotic (reservoir) ecosystem (Azevedo et al. 2006).

The positive correlation between $P_{\max }$ and chl $a$ obtained during the annual surveys was not observed during seasonal tidal cycles, when considering the entire data set. However, if the summer survey is excluded, a significant positive relationship between those variables emerges, although analysis of this relationship for data collected during individual surveys shows this correlation to be somewhat misleading. For each individual survey, an inverse relationship between those variables seems to exist (Fig. 9), suggesting that other factors, such as temperature, should also influence $P_{\max }$ variability over a seasonal timescale. These observations enhance the multivariate facet of photosynthetic response control of natural phytoplankton assemblages within highly dynamic systems. Changes in environmental conditions may influence phytoplankton photosynthesis directly (temperature, light, nutrients) through physiological adaptations or indirectly, through changes in species composition, induced by hydrodynamic alterations. This will depend on the physiological adaptation time of phytoplankton and whether it is longer or shorter than the hydrodynamic changes of the system.

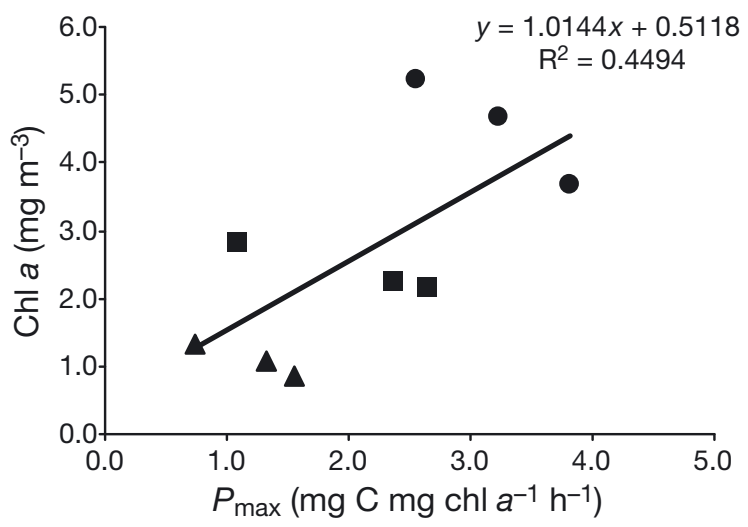

Fig. 9. Relationship between the maximum photosynthetic rate $P_{\max }$ and chl a concentration obtained during spring (0), fall (ם), and winter $(\boldsymbol{\Delta})$ tidal surveys

The attempt to integrate temperature and phosphate-limiting functions in PP estimation showed that the inclusion of temperature improves model performance, while including the phosphate potential limiting effect only works for spring and fall. In fact, modeling of phytoplankton nutrient limitation is not straightforward, since it depends not only on the water's N:P ratio, but also on factors such as nutrient regeneration and intracellular concentration.

\section{CONCLUSIONS}

The results obtained from this study suggest that (1) the most important timescale of $P_{\max }$ and $\alpha$ variability, among those analyzed in the present work, was the seasonal one, although diel variability in summer was also considerable; (2) diel analysis showed that highest values of $P_{\max }$ were found around noon or in the afternoon, while $\alpha$ maxima were observed around noon; (3) $P_{\max }$ was generally higher upstream, decreasing towards the estuary mouth; and (4) light, temperature, and salinity were the most influential factors on $P-E$ parameter variability; additionally, PP prediction accuracy was increased by combining light and temperature-limiting functions.

The relationship observed between salinity and $P-E$ parameters may indicate that variability in these parameters could also be caused by species composition shifts, changing photosynthetic response of the phytoplankton assemblage. Since species composition was not in the framework of the present study, it deserves further research.

Acknowledgements. This work was partially funded by the Porto Water and Waste Water Department (SMAS), through a contract awarded to A.A.B., and by the Portuguese Science and Technology Foundation (FCT), through a $\mathrm{PhD}$ fellowship to I.C.A. (SFRH/BD/4660/2001). 


\section{LITERATURE CITED}

Azevedo IC, Duarte PM, Bordalo AA (2006) Pelagic metabolism of the Douro estuary (Portugal) - factors controlling primary production. Estuar Coast Shelf Sci 69:133-146

> Azevedo IC, Duarte PM, Bordalo AA (2008) Understanding spatial and temporal dynamics of key environmental characteristics in a mesotidal Atlantic estuary (Douro, NW Portugal). Estuar Coast Shelf Sci 76:620-633

Balls PW (1992) Nutrient behavior in 2 contrasting Scottish estuaries, the Forth and Tay. Oceanol Acta 15:261-277

> Basterretxea G, Aristegui J (2000) Mesoscale variability in phytoplankton biomass distribution and photosynthetic parameters in the Canary-NW African coastal transition zone. Mar Ecol Prog Ser 197:27-40

Behrenfeld MJ, Prasil O, Babin M, Bruyant F (2004) In search of a physiological basis for covariations in light-limited and light-saturated photosynthesis. J Phycol 40:4-25

Binder BJ, DuRand MD (2002) Diel cycles in surface waters of the equatorial Pacific. Deep-Sea Res II 49:2601-2617

Bordalo AA (1991) Ecologia do Estuário do rio Douro: abordagem da evolução espaço-temporal e inter-relações na componente planctónica do compartimento microbiológico. $\mathrm{PhD}$ dissertation, Universidade do Porto

Bordalo A, Vieira M (2005) Spatial variability of phytoplankton, bacteria and viruses in the mesotidal salt wedge Douro Estuary (Portugal). Estuar Coast Shelf Sci 63: 143-154

Boyer JN, Christian RR, Stanley DW (1993) Patterns of phytoplankton primary productivity in the Neuse River estuary, North Carolina, USA. Mar Ecol Prog Ser 97:287-297

> Cote B, Platt T (1983) Day-to-day variations in the springsummer photosynthetic parameters of coastal marine phytoplankton. Limnol Oceanogr 28:320-344

Cote B, Platt T (1984) Utility of the light-saturation curve as an operational model for quantifying the effects of environmental conditions on phytoplankton photosynthesis. Mar Ecol Prog Ser 18:57-66

Duarte P (2005) Photosynthesis-irradiance relationships in marine microalgae. In: Rao DVS (ed) Algal cultures analogues of blooms and applications, Vol 2. Science Publishers, Enfield, NH, p 639-670

Duarte P, Macedo MF, da Fonseca LC (2006) The relationship between phytoplankton diversity and community function in a coastal lagoon. Hydrobiologia 555:3-18

Eilers PHC, Peeters JCH (1988) A model for the relationship between light intensity and the rate of photosynthesis in phytoplankton. Ecol Model 42:199-215

Falkowski PG (1981) Light-shade adaptation and assimilation numbers. J Plankton Res 3:203-216

Falkowski PG, Raven JA (1997) Aquatic photosynthesis. Blackwell, London

> Falkowski PG, Wirick CD (1981) A simulation model of the effects of vertical mixing on primary productivity. Mar Biol 65:69-75

Gallegos CL, Platt T, Harrison WG, Irwin B (1983) Photosynthetic parameters of Arctic marine phytoplankton: vertical variations and time scales of adaptation. Limnol Oceanogr 28:698-708

Geider RJ, MacIntyre HL, Kana TM (1996) A dynamic model of photoadaptation in phytoplankton. Limnol Oceanogr 41:1-15

Goosen NK, Kromkamp J, Peene J, van Rijswik P, van Breugel P (1999) Bacterial and phytoplankton production in the maximum turbidity zone of three European estuaries: the Elbe, Westerschelde and Gironde. J Mar Syst 22: 151-171
Grasshoff K, Ehrhardt M, Kremling K (1983) Methods of seawater analysis. Verlag Chemie, Weinheim

Harding LW, Prezelin BB, Sweeney BM, Cox JL (1982) Primary production as influenced by diel periodicity of phytoplankton photosynthesis. Mar Biol 67:179-186

Huisman J, Sommeijer B (2002) Maximal sustainable sinking velocity of phytoplankton. Mar Ecol Prog Ser 244:39-48

Jassby AD, Platt T (1976) Mathematical formulation of relationship between photosynthesis and light for phytoplankton. Limnol Oceanogr 21:540-547

> Jones M (1984) Nitrate reduction by shaking with cadmium: alternative to cadmium columns. Water Res 18:643-646

Jordan TE, Correll DL, Miklas J, Weller DE (1991) Long-term trends in estuarine nutrients and chlorophyll, and shortterm effects of variation in watershed discharge. Mar Ecol Prog Ser 75:121-132

Jouenne F, Lefebvre S, Veron B, Lagadeuc Y (2005) Biological and physicochemical factors controlling short-term variability in phytoplankton primary production and photosynthetic parameters in a macrotidal ecosystem (eastern English Channel). Estuar Coast Shelf Sci 65: 421-439

- Lizon F, Lagadeuc Y, Brunet C, Aelbrecht D, Bentley D (1995) Primary production and photoadaptation of phytoplankton in relation with tidal mixing in coastal waters. J Plankton Res 17:1039-1055

> Lohrenz SE, Fahnenstiel GL, Redalje DG (1994) Spatial and temporal variations of photosynthetic parameters in relation to environmental conditions in coastal waters of the Northern Gulf of Mexico. Estuaries 17:779-795

> MacCaull WA, Platt T (1977) Diel variations in photosynthetic parameters of coastal marine phytoplankton. Limnol Oceanogr 22:723-731

> Macedo MF, Duarte P, Mendes P, Ferreira JG (2001) Annual variation of environmental variables, phytoplankton species composition and photosynthetic parameters in a coastal lagoon. J Plankton Res 23:719-732

> MacIntyre HL, Cullen JJ (1996) Primary production by suspended and benthic microalgae in a turbid estuary: timescales of variability in San Antonio Bay, Texas. Mar Ecol Prog Ser 145:245-268

Madariaga I (2002) Short-term variations in the physiological state of phytoplankton in a shallow temperate estuary. Hydrobiologia 475-476:345-358

> Marra J, Heinemann K, Landriau G (1985) Observed and predicted measurements of photosynthesis in a phytoplankton culture exposed to natural irradiance. Mar Ecol Prog Ser 24:43-50

Moisander PH, McClinton E, Paerl HW (2002) Salinity effects on growth, photosynthetic parameters, and nitrogenase activity in estuarine planktonic cyanobacteria. Microb Ecol 43:432-442

Parsons T, Maita Y, Lalli C (1984) A manual of chemical and biological methods for seawater analysis. Pergamon Press, Elmsford, NY

Pastuszak M, Nagel K, Grelowski A, Mohrholz V, Zalewski M (2003) Nutrient dynamics in the Pomeranian Bay (Southern Baltic): impact of the Oder River outflow. Estuaries 26: 1238-1254

Pereira-Filho J, Schettini CAF, Rorig L, Siegle E (2001) Intratidal variation and net transport of dissolved inorganic nutrients, POC and chlorophyll $a$ in the Camboriu River estuary, Brazil. Estuar Coast Shelf Sci 53: 249-257

Pitcher GC, Walker DR, Mitchell-Innes BA (1989) Phytoplankton sinking rate dynamics in the southern Benguela upwelling system. Mar Ecol Prog Ser 55:261-269 
Platt T, Gallegos CL, Harrison WG (1980) Photoinhibition of photosynthesis in natural assemblages of marine phytoplankton. J Mar Res 38:687-701

Prezelin BB (1992) Diel periodicity in phytoplankton productivity. Hydrobiologia 238:1-35

Sakshaug E, Bricaud A, Dandonneau Y, Falkowski PG and others (1997) Parameters of photosynthesis: definitions, theory and interpretation of results. J Plankton Res 19: 1637-1670

SCOR (Scientific and Cultural Organisation)-UNESCO (1966) Determination of photosynthetic pigments in seawater. Report of the SCOR-UNESCO working group 17. Monographs on oceanographic methodology. UNESCO, Paris, p 11-18

Snow GC, Adams JB, Bate GC (2000) Effect of river flow on estuarine microalgal biomass and distribution. Estuar Coast Shelf Sci 51:255-266

Editorial responsibility: Rodney Forster, Lowestoft, UK
Steele JH (1962) Environmental control of photosynthesis in the sea. Limnol Oceanogr 7:137-150

Steeman Nielsen E (1952) The use of radioactive carbon $\left({ }^{14} \mathrm{C}\right)$ for measuring organic production in the sea. J Cons Int Explor Mer 18:117-140

Struski C, Bacher C (2006) Preliminary estimate of primary production by phytoplankton in Marennes-Oleron Bay, France. Estuar Coast Shelf Sci 66:323-334

Tillmann U, Hesse KJ, Colijn F (2000) Planktonic primary production in the German Wadden Sea. J Plankton Res 22: 1253-1276

- Vieira M, Bordalo AA (2000) The Douro estuary (Portugal): a mesotidal salt wedge. Oceanol Acta 23:585-594

- Webb WL, Newton M, Starr D (1974) Carbon dioxide exchange of Alnus rubra: a mathematical model. Oecologia $17: 281-291$

Submitted: February 11, 2010; Accepted: May 24, 2010 Proofs received from author(s): August 9, 2010 